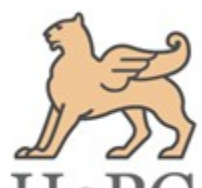

Research Article

\title{
Two species of Isopterygium Mitt. - New to the Eastern Ghats in Peninsular India
}

\author{
P. M. Biju and A. E. D. Daniels* \\ Bryology Laboratory, Department of Botany \& Research Centre, Scott Christian College (Autonomous), Nagercoil - 629 003, Tamil \\ Nadu, India
}

Article history

Received: 24 March 2016

Accepted: 30 March 2016

Published: 12 April 2016

(C) Biju and Daniels (2016)

Special Section: New Frontiers in Cryptogamic Botany

Section Editor

Afroz Alam

Publisher

Horizon e-Publishing Group

Corresponding Author

A. E. D. Daniels

$\bigotimes_{\text {dulipdaniels@rediffmail.com }}$

\begin{abstract}
Isopterygium lignicola and I. longitheca are new to the bryoflora of the Eastern Ghats. Of these, I. longitheca is new to Peninsular India. The present discovery extends its distribution to the southern end of the country. Brief descriptions with illustrations and photo plates are provided here. A key is provided for those species in discussion.
\end{abstract}

Keywords

Bryophyta; Eastern Ghats; Isopterygium lignicola; I. longitheca; mosses

Biju, P. M., and A. E. D. Daniels. 2016. Two species of Isopterygium Mitt. New to the Eastern Ghats in Peninsular India. Plant Science Today 3(2): 129-134. http://dx.doi.org/10.14719/pst.2016.3.2.223

\section{Introduction}

Isopterygium Mitt. is a cosmopolitan genus with about 150 species world-wide (www.tropicos.org), most of which occur in the tropical and subtropical belts of the globe (Gangulee, 1980). Of these, 20 species occur in India (Lal, 2005; Dandotiya et al., 2011). From the Western Ghats, so far, 9 species have been reported.

Iwatsuki (1970) proposed a new genus Isopterygiopsis and transferred Isopterygium muellerianum (Schimp.) A. Jaeger under Isopterygiopsis Iwats. and made a new combination Isopterygiopsis muelleriana (Schimp.) Iwats. Iwatsuki (1970) also transferred Isopterygium seligeri (Brid.) Dixon ex Jensen under Herzogiella Broth. and made another combination Herzogiella seligeri (Brid.) Iwats. Iwatsuki (1987), transferred yet another species of Isopterygium viz., $I$. pulchellum (Hedw.) A. Jaeger under Isopterygiopsis
Iwats. and made another combination Isopterygiopsis pulchella (Hedw.) Iwats. Moreover, he (Iwatsuki, 1987) raised and validated Pseudotaxiphyllum, a section under Isopterygium to genus rank and transferred a host of species under it including three of Isopterygium occurring in India namely, $I$. distichaceum (Mitt.) A. Jaeger, $I$. pohliaecarpum (Sull. \& Lesq.) A. Jaeger and $I$. elegans Brid. Considering all these changes, in India, currently there are only 14 species of Isopterygium Mitt. of which 6 have been reported from the Western Ghats and one from the Eastern Ghats. Further studies on this genus may alter the number of species so far reported from India.

Kumar and Krishnamurthy (2007) reported 59 species of mosses from Shervaroy Hills. However, not a single species of Isopterygium Mitt. has been enumerated. Sathish et al. (2014) in their checklist of mosses of Kalrayan Hills of the E. Ghats, included one species namely I. albescens (Hook.) A. Jaeger. 


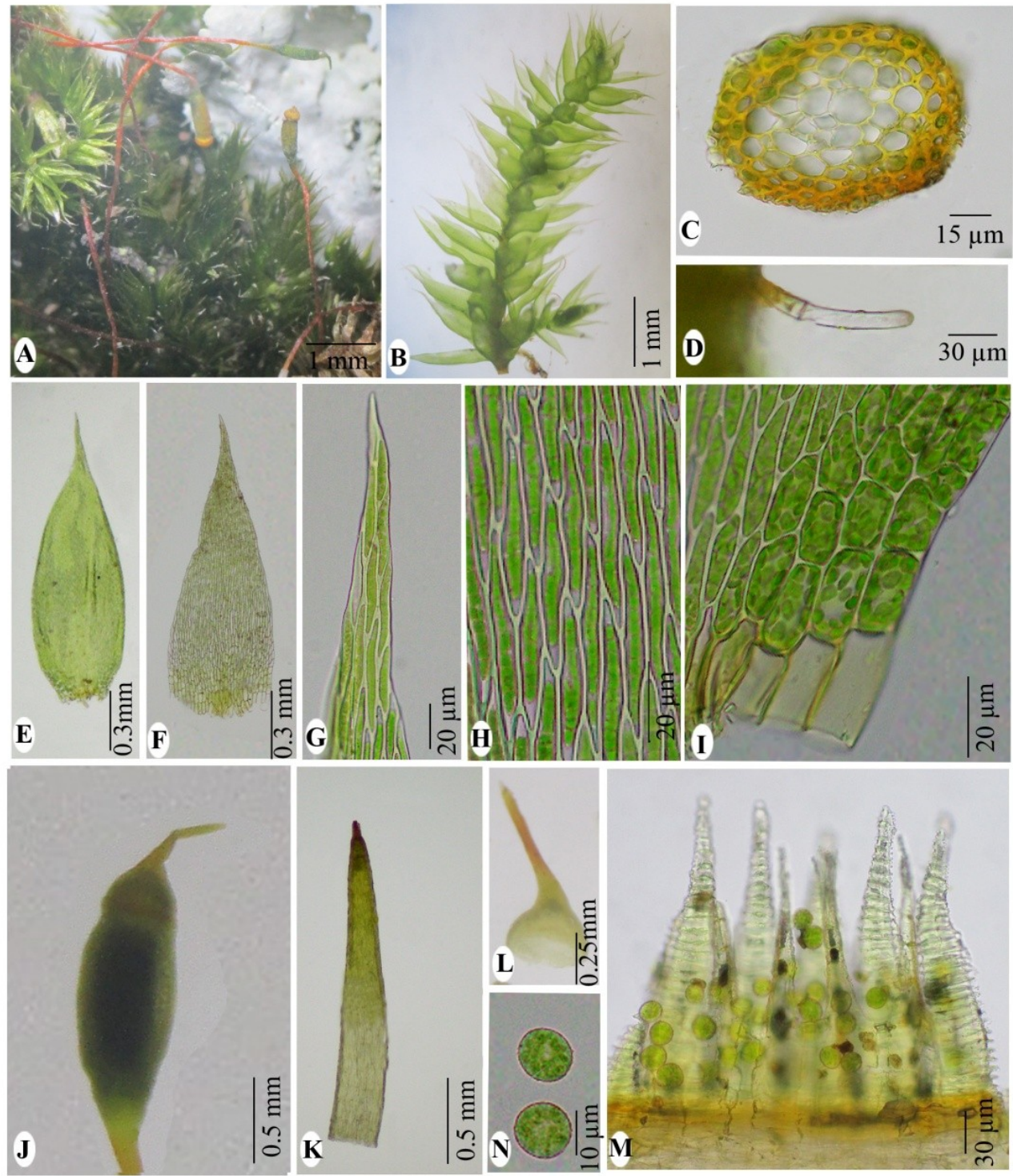

Plate 1(A-N). Isopterygium lignicola (Mitt.) A. Jaeger

A. Habitat B. Portion of plant C. Cross section of stem D. Paraphyllia

E. Leaf F. Perichaetial leaf G. Leaf apical cells H. Leaf median cells I. Leaf basal cells J. Capsule K. Calyptra L. Operculum M. Peristome teeth N. Spores

The present survey made on the Shervaroy Hills of the Eastern Ghats records the occurrence of two more species namely Isopterygium lignicola (Mitt.) A. Jaeger and I. longitheca (Mitt.) A. Jaeger that are new to the bryoflora of the Eastern Ghats. Of these, I. longitheca is new to Peninsular India. Until now, this species was known only from the Eastern Himalaya and was thought to be an Eastern Himalayan endemic. The present discovery extends its distribution to the southern end of the country. Brief descriptions with illustrations and photo plates are provided here. A key is provided for the species in discussion. The specimens are housed at SCCN.

\section{Key to the species}

1a. Leaves erectopatent, with a row of rectangular cells along insertion line, faintly crenulate at margin; calyptrae not apiculate b. Leaves patent, without a row of rectangular cells along insertion line, entire at margin; calyptrae apiculate I. lignicola

Note: Isopterygium albescens can be readily distinguished from both the species in discussion by its ovate leaves and acute to short-acuminate leaf apices.

1. Isopterygium lignicola (Mitt.) A. Jaeger, Ber. Thätigk. St. Gallischen Naturwiss. Ges.: 432. 1878; Bruehl, Rec. Bot. Surv. India 13(1): 112. 1931; R.S. Chopra, Taxon. Indian Moss.: 534. 1975; Gangulee, Moss. E. India 3(8): 1964, f. 1011. 1980; A.E.D. Daniels in R. Annamalai, Tamil Nadu Biodivers.: 54. 2004 \& Arch. Bryol. 65: 66. 2010; J. Lal, Checklist Indian Moss.: 80. 2005; Manju \& al., Trop. Bryol. Res. Rep. 7: 14. 2008 \& Arch. Bryol. 42: 8. 


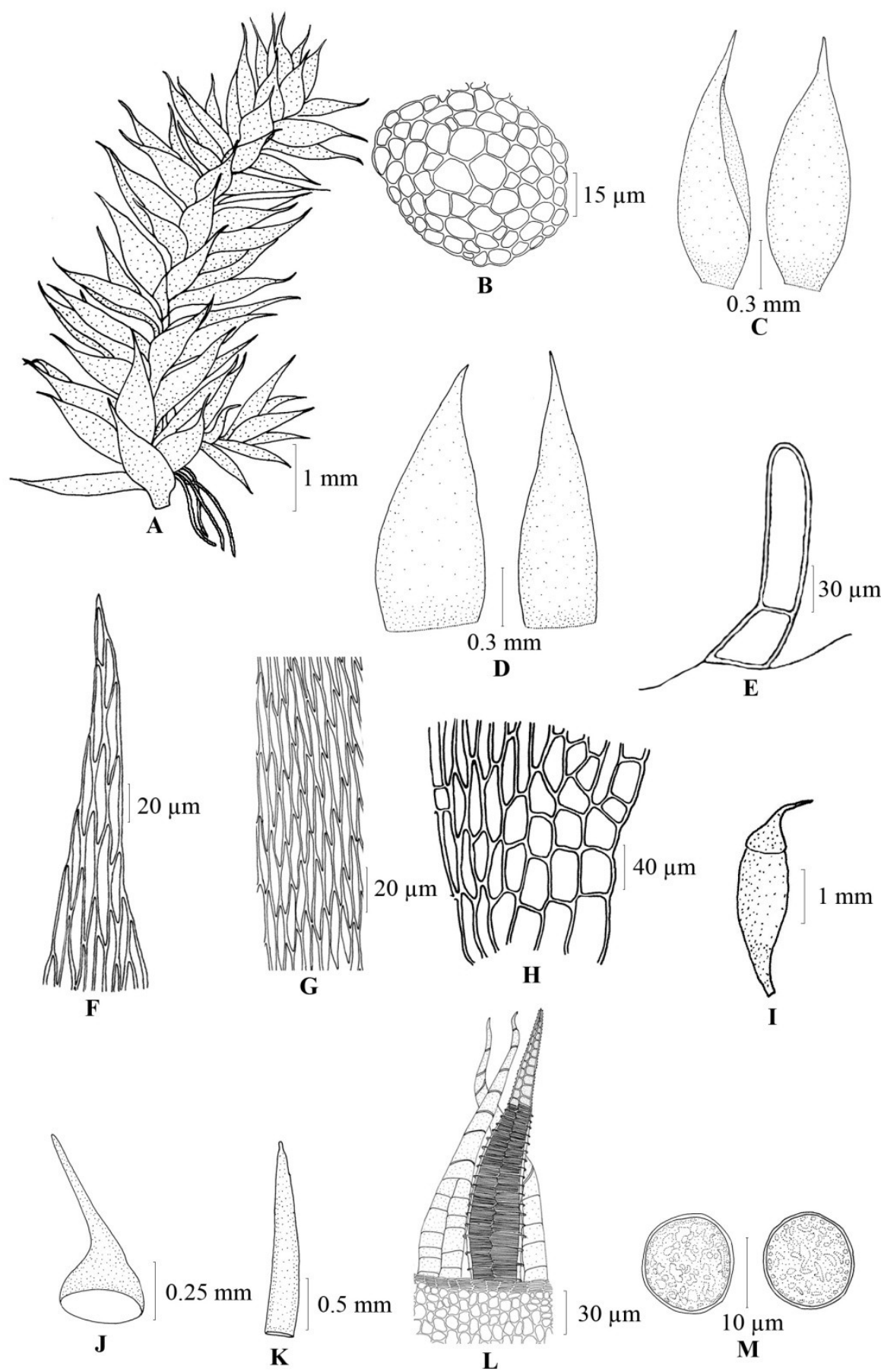

Fig. 1 (A - M). Isopterygium lignicola (Mitt.) A. Jaeger

A. Portion of plant B. Cross section of stem C. Leaves D. Perichaetial leaves E. Paraphyllia F. Leaf apical cells G. Leaf median cells H. Leaf basal cells I. Capsule J. Operculum K. Calyptra L. Peristome teeth M. Spores (Drawn from Daniels \& Biju11420)

2009; A.E.D. Daniels \& P. Daniel, Bryofl. S.-most W. Ghats, India: 146. 2013. Hypnum lignicola Mitt., Hooker's J. Bot. Kew Gard. Misc. 8: 355.1856. Type: Burma (Myanmar), Moulmein, Parish 12 (NY). Stereodon lignicola (Mitt.) Mitt., J. Proc. Linn. Soc., Bot. 1 (Suppl.): 104. 1859. (Fig. 1; Plate 1)

Plants forming mats, slender, yellow-green above, brownish below, glossy. Stems creeping, 0.6 $2 \mathrm{~cm}$ long, ca $0.13 \times 0.10 \mathrm{~mm}$ in cross section, ovate, without a central strand; cortex 1- or 2- layered; cells $8-12 \times 7-10 \mathrm{~mm}$, thick-walled; medullary ones $12-20 \times 10-18 \mathrm{~mm}$, thin-walled; branches pinnate. Paraphyllia not clustered, 2- or 3-celled, linear, ca $0.1 \times 0.01 \mathrm{~mm}$. Leaves patent, concave, $1 \quad 1.2 \times 0.2 \quad 0.4 \mathrm{~mm}$, ovate-lanceolate, entire at margin, long-acuminate with a long, narrow acumen, ecostate; cells linear, smooth; apical cells 32 - $44 \times 4$ - $8 \mu \mathrm{m}$; median ones $44-52 \times$ 4 - $8 \mu \mathrm{m}$; basal ones $16-32 \times 8-20 \mu \mathrm{m}$, with a few swollen and hyaline at extreme angles. Perichaetial leaves ca $1 \times 0.5 \mathrm{~mm}$, oblong-ovate, 

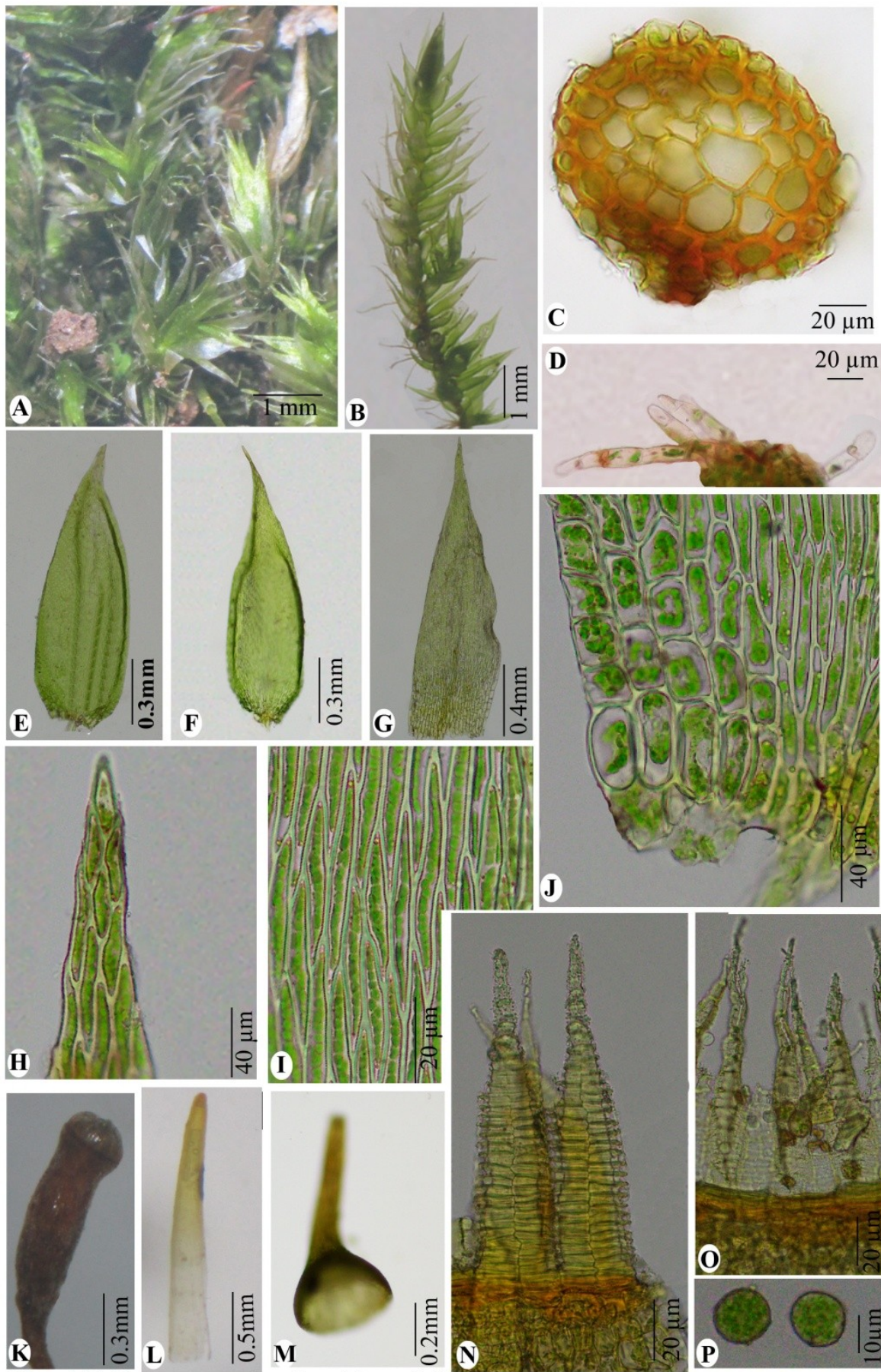

Plate 2(A-P). Isopterygium longitheca (Mitt.) A. Jaeger

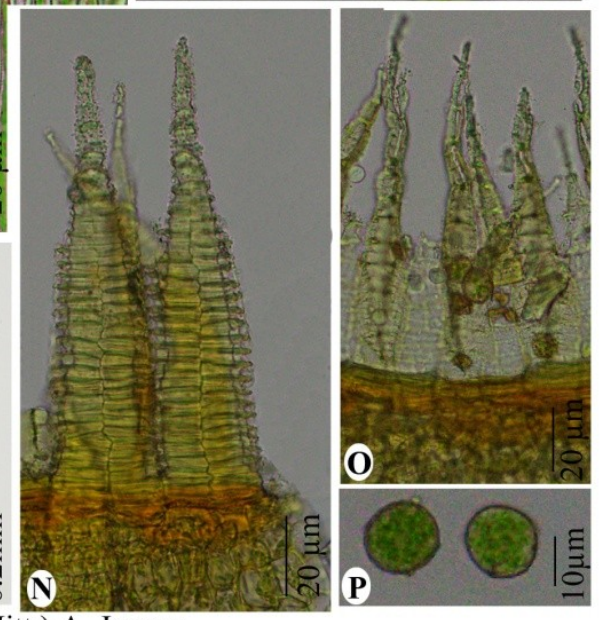

A. Habitat B. Portion of plant C. Cross section of stem D. Paraphyllia

E\&F. Leaves G. Perichaetial leaf H. Leaf apical cells I. Leaf median cells J. Leaf basal cells K. Capsule L. Calyptra M. Operculum N. Peristome teeth outer surface $\mathbf{O}$. Inner surface $\mathbf{P}$. Spores

acuminate. Sporophytes on main stems. Setae erect, ca $6 \mathrm{~mm}$ high. Calyptrae ca $2 \times 0.5 \mathrm{~mm}$, cucullate, narrow, apiculate. Capsules inclined to horizontal, ca $1.2 \times 0.4 \mathrm{~mm}$, ovoid-cylindric. Operculum conic, long-rostrate. Peristome teeth 2rowed; outer row ca $0.24 \times 0.04 \mathrm{~mm}$, segmented, lamellate, papillose; inner row ca $0.18 \times 0.03 \mathrm{~mm}$, papillose. Spores ca $12 \mu \mathrm{m}$, globose, papillose.

Habitat: Rupicolous in moist deciduous forests, ca $1020 \mathrm{~m}$.
Distribution: Myanmar, Sri Lanka and India: Eastern Himalaya (Sikkim), NE. India (Meghalaya), Western Ghats of Karnataka, Kerala, Tamil Nadu and Eastern Ghats of Tamil Nadu (Salem).

Specimens examined: Eastern Ghats: Tamil Nadu, Salem Dist., Shervaroy Hills, ca 1020 m, 12.8.2015, A.E.D. Daniels \& P.M. Biju11420.

2. Isopterygium longitheca (Mitt.) A. Jaeger, Ber. Thätigk. St. Gallischen Naturwiss. Ges.: 432. 1878; Gangulee, Moss. E. India 3(8): 1955, f. 1011. 1980. 


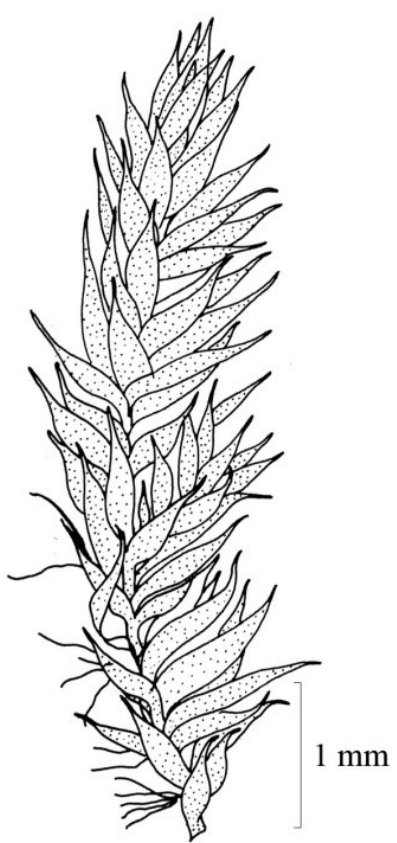

A

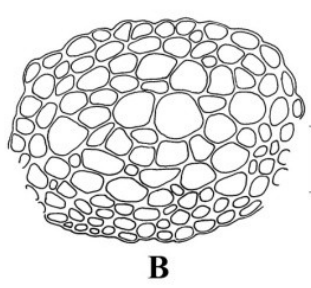

$20 \mu \mathrm{m}$

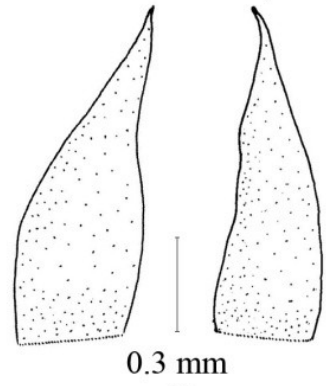

D

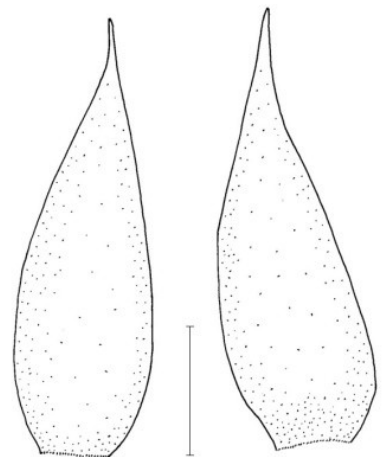

$0.25 \mathrm{~mm}$

C

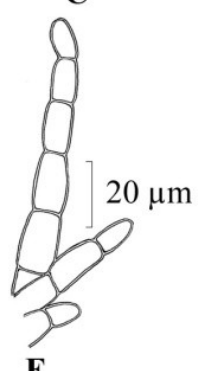

E

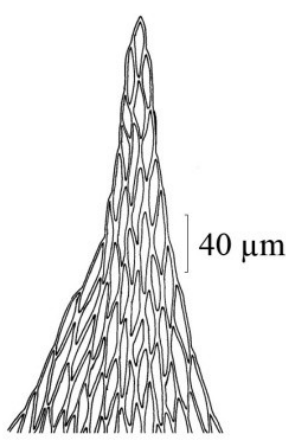

F

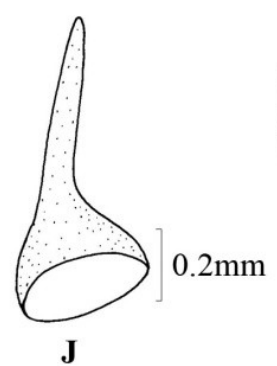

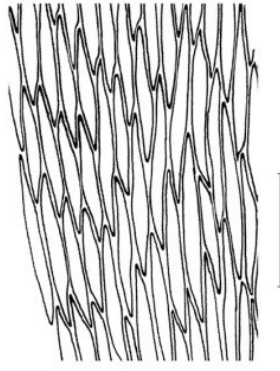

G
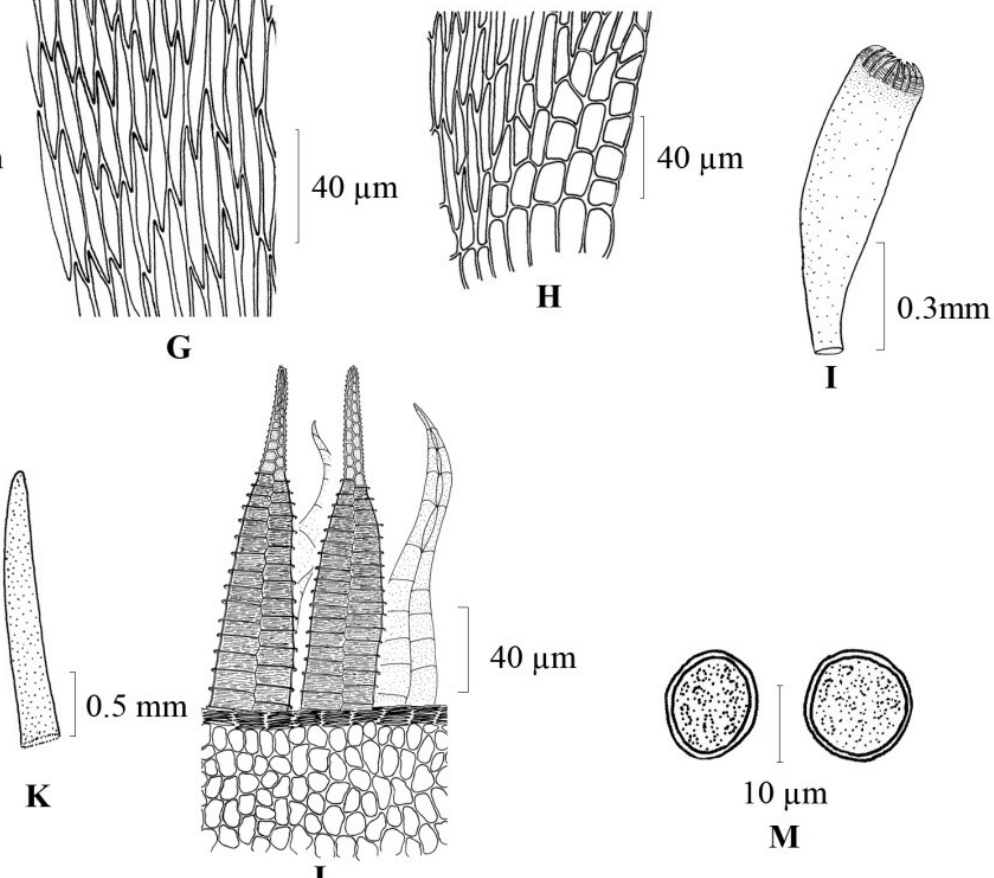

$\mathbf{L}$

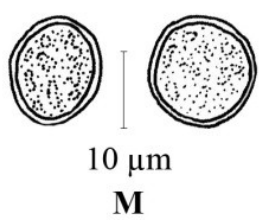

Fig. 2(A-J). Isopterygium longitheca (Mitt.) A. Jaeger

A. Portion of plant B. Cross section of stem C. Leaves D. Perichaetial leaves

E. Paraphyllia F. Leaf apical cells G. Leaf median cells H. Leaf basal cells

I. Capsule J. Operculum K. Calyptra L. Peristome teeth M. Spores

(Drawn from Daniels \& Biju 11388 p.p.)

Stereodon longitheca Mitt., J. Proc. Linn. Soc., Bot. 1 (Suppl.): 104. 1859. -Type: India, Himalaya, Darjeeling, Tongloo, J. D. Hooker 1152 (BM). (Fig. 2; Plate 2).

Plants forming mats, slender, yellow-green above, brownish below, glossy. Stems creeping, irregularly pinnately branched, complanate, 0.5 $1.5 \mathrm{~cm}$ long, ca. $0.12 \times 0.08 \mathrm{~mm}$ in cross section, ovate, without a central strand; cortex 1- or 2- layered; cells 8 - $12 \times 4-8 \mathrm{~mm}$, thick-walled; medullary ones $20-28 \times 16-20 \mathrm{~mm}$, thin-walled. Paraphyllia clustered, 2 - 6-celled, linear, ca. $0.14 \times$ $0.02 \mathrm{~mm}$. Leaves erectopatent, concave, $11.7 \times 0.4$

$0.6 \mathrm{~mm}$, ovate-lanceolate, entire, sometimes revolute on one side at base, long-acuminate and faintly crenulate at apex, ecostate; cells linear, smooth; apical cells 32 - $48 \times 4$ - $8 \mu$ m; median ones $48-60 \times 4-8 \mu \mathrm{m}$; basal ones $28-38 \times 8-20 \mu \mathrm{m}$, 
with one row of rectangular cells along the insertion line. Perichaetial leaves ca. $1.2 \times 0.4 \mathrm{~mm}$, oblong-ovate, acuminate. Sporophytes on main stems. Setae erect, ca. $9 \mathrm{~mm}$ high. Calyptrae ca. 1.8 $\times 0.2 \mathrm{~mm}$, cucullate, narrow, not apiculate. Capsules inclined, ca. $1 \times 0.3 \mathrm{~mm}$, cylindrical. Operculum conic, long-rostrate. Peristome teeth 2rowed; outer row ca. $0.23 \times 0.06 \mathrm{~mm}$, segmented, lamellate, papillose; inner row ca. $0.17 \times 0.04 \mathrm{~mm}$, papillose. Spores ca. 16x16 $\mu \mathrm{m}$ in diameter, globose, papillose.

Habitat: Lignicolous, and corticolous on Albizia sp. (Mimosaceae), ca. $1020 \mathrm{~m}$.

Distribution: India: Eastern Himalaya and Eastern Ghats of Tamil Nadu (Salem).

Specimens examined: Eastern Ghats: Tamil Nadu, Salem Dist., Shervaroy Hills, ca. 1020 m, 11.8.2015, A.E.D. Daniels \& P.M. Biju 11388 p.p., 11393 p.p.

\section{Discussion}

The Eastern Ghats is more or less an unexplored region in terms of bryophyte diversity. However, like the Western Ghats, this region is also rich in bryophyte diversity which is evident by the number of new reports made by Kumar and Krishnamurthy (2007) and Sathish et al. (2014). The present study also strengthens this fact, as Isopterygium lignicola and I. longitheca are being reported new to the bryoflora of the Eastern Ghats and Peninsular India respectively.

\section{Acknowledgements}

We thank the Tamil Nadu State Forest Department for permission to explore the study area and help in the field. AEDD thanks the Ministry of Environment \& Forests and Climate Change, New Delhi, for financial assistance, and the Principal, Scott Christian College, for facilities.

\section{References}

Dandotiya, D., H. Govindapyari, S. Suman, and P. L. Uniyal. 2011. Checklist of the bryophytes of India. Arch Bryol 88: 1 - 126.

Iwatsuki, Z. 1970. A revision of Plagiothecium and its related genera from Japan and her adjacent areas I. J Hattori Bot Lab 33: 331 - 380.

Iwatsuki, Z. 1987. Notes on Isopterygium Mitt. (Plagiotheciaceae). J Hattori Bot Lab 63: 445 451.

Kumar, G. V. and K. V. Krishnamurthy 2007. Moss flora of Shervaroy Hills of Eastern Ghats (South India). In: Nath, V. \& A.K. Asthana (eds.), Current Trends in Bryology, 227 - 243. Bishen Singh Mahendra Pal Singh, Dehra Dun.

Lal, J. 2005. A checklist of Indian mosses. Bishen Singh Mahendra Pal Singh, Dehra Dun, India.

Sathish, S. S., T. Thamizharasi, R. Palani, P. Vijayakanth, and A. Vimala. 2014. Checklist of mosses (Bryopsida) of the Kalrayan Hills in the Eastern Ghats of Tamil Nadu, India. Eng Biosci 2: $28-33$. 